\title{
Nutritional vulnerability of early zoea larvae of the crab Maja brachydactyla (Brachyura, Majidae)
}

\author{
G. Guerao ${ }^{1, *}$, C. G. Simeó ${ }^{1}$, K. Anger ${ }^{2}$, Á. Urzúa ${ }^{2,3}$, G. Rotllant ${ }^{1}$ \\ ${ }^{1}$ IRTA, Unitat Operativa de Cultius Experimentals. Ctra. Poble Nou, Km 5.5, 43540 Sant Carles de la Ràpita, Tarragona, Spain \\ ${ }^{2}$ Biologische Anstalt Helgoland, Meeresstation, Alfred-Wegener-Institut für Polar- und Meeresforschung, 27498 Helgoland, \\ Germany \\ ${ }^{3}$ Mathematisch-Naturwissenschaftliche Fakultät, Christian-Albrechts-Universität zu Kiel, 24118 Kiel, Germany
}

\begin{abstract}
We investigated the nutritional vulnerability of Zoeae I of the spider crab Maja brachydactyla in experimental treatments with differential periods of starvation. As response variables, the moulting and survival rates, the point-of-reserve-saturation (PRS), the point-of-noreturn (PNR), dry mass, elemental composition (carbon, hydrogen, nitrogen; CHN), hepatopancreas lipid vacuoles and activities of digestive enzymes were measured. Average median time spans when $50 \%$ of the larvae reached PNR or PRS ( PNR $_{50}$ and $\mathrm{PRS}_{50}$ ) values were 2.8 and $1.9 \mathrm{~d}$, respectively. In PNR treatments, complete mortality occurred only after extended initial starvation periods of $\geq 5 \mathrm{~d}$, and in PRS treatments, Zoeae I were capable of completing the moulting cycle after a short initial feeding period (1 d). In continuously starved control larvae, the moulting cycle was arrested at the onset of apolysis. Concomitantly, considerable amounts of biomass were lost and the C:N ratio decreased, indicating lipid degradation during starvation. This effect was also microscopically visible as a decline of lipid vacuoles in the hepatopancreas. Feeding after previous starvation periods of $<7 \mathrm{~d}$ resulted in a re-establishment of the lipid vacuoles, indicating successful capture and ingestion of food, but this did not necessarily allow for completing the moulting cycle. In fed Zoea I larvae, digestive enzyme activities increased during the moulting cycle, while a significant decrease of enzyme activities occurred under starvation conditions. In newly moulted Zoeae II, biomass values and enzyme activities were linearly correlated with the duration of the feeding periods in Zoeae I. This study shows that biomass, elemental composition, the occurrence of lipid vacuoles in the hepatopancreas and activities of digestive enzymes are suitable indicators of the nutritional condition of early zoeal stages of $M$. brachydactyla.
\end{abstract}

KEY WORDS: Decapoda · Majoidea · Starvation · Point-of-no-return · Point-of-reserve-saturation · $\mathrm{CHN} \cdot$ Hepatopancreas $\cdot$ Condition indices

Resale or republication not permitted without written consent of the publisher

\section{INTRODUCTION}

One of the key factors affecting the survival of larvae in the plankton is the patchy and unpredictable nature of food abundance (Yin \& Blaxter 1987, Morgan 1995, Pechenik et al. 1996). The capacity of the decapod malacostracan larval stages to tolerate temporary periods of starvation is therefore believed to be essential for their survival in the pelagic environment, particularly in nutritionally unstable habitats
(Anger 2001). In newly hatched larvae, fitness is largely determined by initially available yolk resources, which may vary intra- and interspecifically, depending e.g. on seasonal, genetic or maternal factors, and the conditions prevailing during the preceding period of embryonic development (Anger 1995, Giménez et al. 2004, Paschke et al. 2004, Giménez \& Anger 2005).

As the initially available yolk reserves may rapidly be catabolized in the absence of food, decapod larvae 
must start feeding soon after hatching to avoid deleterious effects caused by starvation. In previous studies, the effects of food limitation at a scale of 1 or a few days were mostly evaluated by means of 'pointof-no-return' (PNR) and 'point-of-reserve-saturation' (PRS) experiments, which yield indices of critical points that can be used to compare the degree of nutritional vulnerability in different species or developmental stages (Anger 2001, Gebauer et al. 2010). The PNR is defined as the threshold time at which initially starved larvae have lost the capability to recover from nutritional stress and to moult during subsequent feeding periods, whereas the PRS is the minimum time of initial feeding at which sufficient reserves are accumulated to subsequently complete a larval stage in principle independent of further food supply (Anger \& Dawirs 1981).

Knowledge of such critical points in the early larval stages may provide valuable tools for the assessment of the physiological condition of larvae in the field, or for the establishment of successful rearing protocols for aquaculture of commercially valuable decapod crustacean species, helping to enhance larval survival to metamorphosis (Rotllant et al. 2010). Variations in the proportions of various chemical fractions of biomass, e.g. the contents of carbon, nitrogen and hydrogen (collectively referred to as $\mathrm{CHN}$ ), have frequently been used as indicators of larval condition (e.g. Dawirs 1986, Thatje et al. 2004) or 'quality' (Andrés et al. 2010a). Digestive enzyme activities have also recently been applied to evaluate the nutritional condition of larvae (Rotllant et al. 2008, 2010, Andrés et al. 2010b). Furthermore, changes in biomass during individual moult cycles may be used to quantitatively describe and compare the basic patterns of development and growth in decapod larvae (Anger 2001, Rotllant et al. 2012).

The spider crab Maja brachydactyla Balss, 1922 (Brachyura, Majoidea) is potentially interesting for aquaculture and has therefore been intensively studied in recent years (e.g. Andrés et al. 2007, Guerao et al. 2008). The larval development of this species comprises 2 zoeal stages and a megalopa, which can successfully be reared under intensive and semiextensive cultivation conditions, allowing for satisfactory growth and survival (Andrés et al. 2007). The nutritional vulnerability of its larval stages may have practical applications for maximizing feeding efficiency and enhancing rates of growth and survival. Effects of food deprivation were previously studied in mass culture (Rotllant et al. 2010), showing that all 3 larval stages of this species are planktotrophic and that a decrease in food supply causes increased development duration and decreased growth and survival.

The aim of the present study was to quantify the nutritional vulnerability of first-stage zoeae of Maja brachydactyla in terms of survival, development time, PNR and PRS indices, changes in dry mass and elemental composition (CHN), effects on the duration of stages within the moulting cycle (Guerao et al. 2010), the appearance of microscopically visible lipid droplets in the digestive gland and activities of digestive enzymes (amylase and protease), testing these response variables as potential indicators of larval condition. Moreover, we considered the variability among individually tested larvae, enhancing the accuracy of all results compared to previous experiments using mass culture techniques.

\section{MATERIALS AND METHODS}

\section{Maintenance of broodstock and collection of larvae}

Adult Maja brachydactyla were captured in January 2010 off the coast of Galicia, Spain, northeastern Atlantic), and transported in cooling containers (ca. $8^{\circ} \mathrm{C}$ ) to the Institut de Recerai Tecnologica Agroalementàries (IRTA; Sant Carles de la Ràpita). Ovigerous females were kept in $1500 \mathrm{l}$ broodstock tanks connected to a recirculation unit maintaining a constant salinity of 36 and a temperature of 18 to $19^{\circ} \mathrm{C}$. In September and October 2010, larvae were released from 2 different females. Immediately after hatching, actively swimming Zoea I larvae were collected from the broodstock tanks and transferred to individual experimental beakers with $50 \mathrm{ml}$ seawater kept at a salinity of 36 , constant temperature of $18^{\circ} \mathrm{C}$ and a 12:12 h light:dark photoperiod. A total of 960 Zoeae I were used to study survival and duration of the Zoea I moulting cycle, and 4000 larvae were used for biochemical and histological analyses.

\section{PNR and PRS experiments}

PNR experiments included a series of 4 treatments with differential periods of initial starvation followed by continuous feeding (Fig. 1A), as well as a continuously starved (SC) and a continuously fed control (FC) group (80 Zoeae I in each treatment and control). In PRS experiments, there were 4 treatments with differential periods of initial feeding followed by starvation (Fig. 1B). Where applicable, freshly hatched Artemia franciscana (Kellog 1906) nauplii 

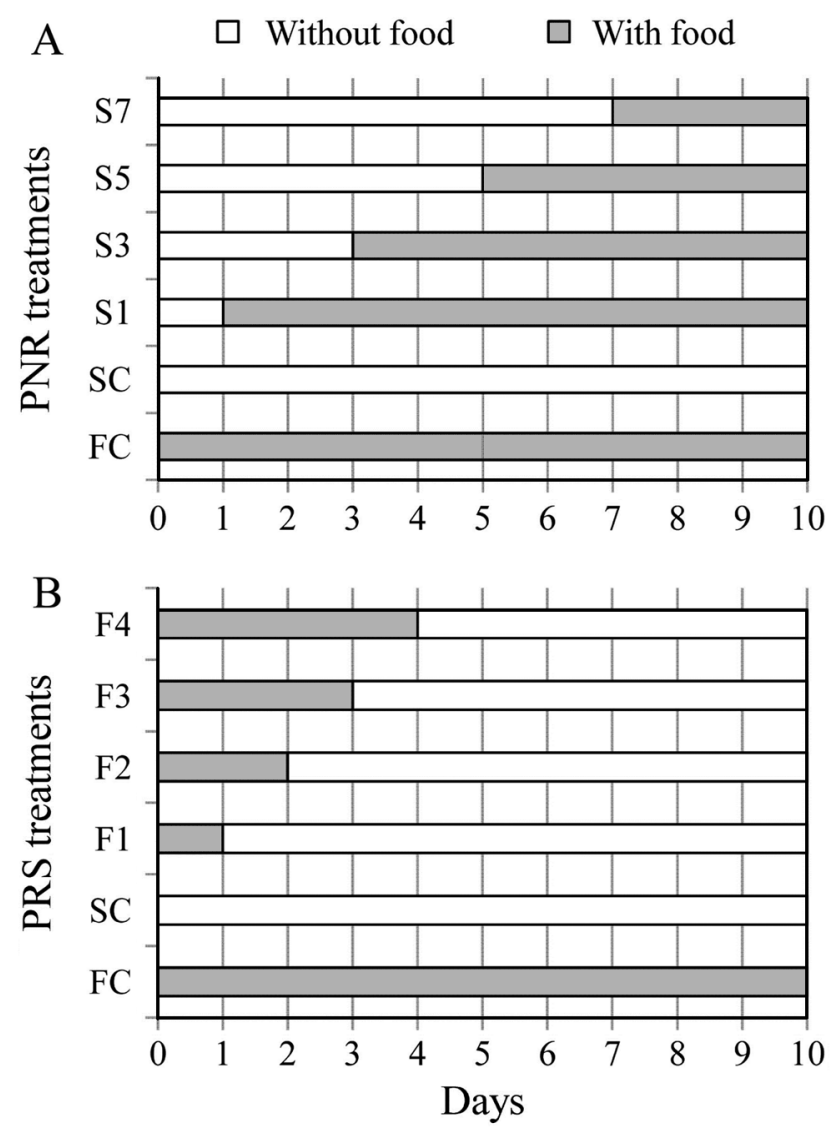

Fig. 1. Maja brachydactyla. Experimental design. (A) Pointof-no-return (PNR) experiments, with initial starvation periods followed by feeding ( $\mathrm{SC}=$ continuously starved control; treatments: $\mathrm{S} 1=1 \mathrm{~d}, \mathrm{~S} 3=3 \mathrm{~d}$ of starvation, etc.); (B) point-ofreserve-saturation (PRS) treatments, with initial periods of feeding followed by starvation ( $\mathrm{FC}=$ continuously fed control; treatments: F1 = $1 \mathrm{~d}$ of feeding, etc.); time of development (d) through the Zoea I moulting cycle

(Great Salt Lake strain, Utah) were used as food. Nutritional vulnerability was expressed as the median time span when $50 \%$ of the larvae reached the PNR or PRS, respectively $\left(\mathrm{PNR}_{50}, \mathrm{PRS}_{50}\right)$, and as a $\mathrm{PRS}_{50}: \mathrm{PNR}_{50}$ quotient (nutritional vulnerability index, NVI; Gebauer et al. 2010). $\mathrm{PNR}_{50}$ and $\mathrm{PRS}_{50}$ values were calculated adjusting the sigmoidal Boltzmann model with the least-squares method to the data (Gebauer et al. 2010).

\section{Biochemical analyses}

Analyses of dry mass (DM) and CHN were carried out at the Marine Biological Station Helgoland (Alfred Wegener Institute for Polar and Marine Research, BAH/AWI, Germany) following standard techniques (Anger \& Harms 1990; for more and updated details, see Andrés et al. 2008). For each mean value, 5 replicate analyses with 3 (Zoea I) or 2 (Zoea II) larvae per replicate measurement were carried out. A fluorometric technique was chosen to measure digestive enzyme activities in individual larvae (total activity, IU ind. ${ }^{-1}$ ). Individual variability was evaluated from replicates of 15 larvae (for details see Rotllant et al. 2008, 2010, 2012). In $\mathrm{n}=5$ replicate samples of larvae, larval moulting stages were determined using the same techniques and classification criteria as described by Guerao et al. (2010).

\section{Histological observations}

For histological inspection of the digestive gland, 5 larvae from each treatment were fixed in Davison's solution (glacial acetic acid, $100 \mathrm{ml} ; 95 \%$ ethyl alcohol, $300 \mathrm{ml} ; 10 \%$ neutral buffered formalin, $200 \mathrm{ml}$; distilled water, $300 \mathrm{ml}$ ) for $24 \mathrm{~h}$ and embedded in paraffin (Humason 1979). Sections of $3 \mu \mathrm{m}$ were stained with haematoxylin-eosin solution. Measurements of lipid vacuoles in the digestive gland were made using a Leica DM LB microscope equipped with an Olympus DP 70 digital camera and an image analysing system (AnalySIS, SIS). The accumulation of lipids was estimated from histological sections $(40 \times)$ as a percentage of the total area occupied by vacuoles (vacuole index, VI, in \%).

\section{Statistical analyses}

Statistical analyses followed standard techniques as described by Sokal \& Rohlf (1995). The response variables biomass (DM, CHN) and digestive enzyme activities were analysed using 1-way analysis of variance (ANOVA), considering the number of days of feeding or starvation (PNR, PRS) as experimental factors or explanatory variables, with separate analyses for each zoeal stage. Subsequent to ANOVA, a posteriori comparisons were made among treatments using the Student-Newman-Keuls (SNK) test for parametric data or the non-parametric Dunn's test for data sets of unequal size. Homogeneity of variance and normality were checked with Levene and Kolmogorov-Smirnov tests, respectively. When the data did not meet the assumptions, the non-parametric Kruskal-Wallis test was applied. Additionally, relationships between the $\mathrm{C}: \mathrm{N}$ ratio and digestive enzymatic activities of Zoeae II, and feeding periods of Zoeae I were tested by linear regression analyses using the equation $y=a x+b$. 

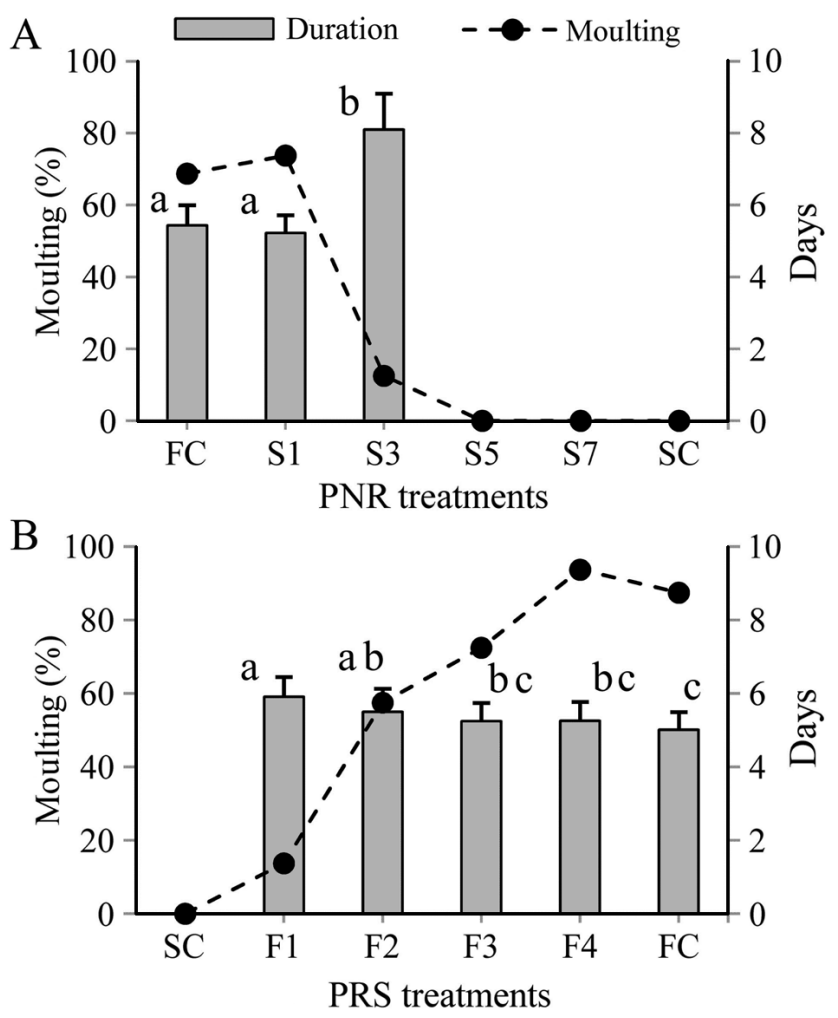

Fig. 2. Maja brachydactyla. Survival and developmental duration of the Zoea I stage. (A) point-of-no-return (PNR) treatments; (B) point-of-reserve-saturation (PRS) treatments; different lowercase letters indicate significant differences among days (SNK or Dunn's test)

\section{RESULTS}

\section{PNR experiment}

The number of days of initial lack of food supply significantly affected larval survival. In all treatments with starvation periods of $\geq 5$ d followed by feeding, no larva was able to recover from initial starvation stress, and complete mortality occurred after a maximum of $10 \mathrm{~d}$ and without moulting to Zoeae II (Fig. 2A). PNR $_{50}$ was 2.8 d. Starvation also affected development duration (Fig. 2A), which was significantly longer in Treatment S3 (see Fig. 1 for a complete description of the treatments) compared to S1 and to the FC group (Fig. 2A).

In the FC group, biomass (DM and CHN values per larva) and the $C: N$ ratio increased during the time from hatching to moulting to the Zoea II stage (Fig. 3A, Table 1). In larvae kept under continuous starvation (SC group), by comparison, biomass decreased significantly (Table 1 ); the $\mathrm{C}: \mathrm{N}$ ratio decreased initially, but after Day 4 it increased tem- porarily (Fig. 3A). In Treatments S1, S3 and S5, biomass and $C: N$ values increased after the end of the starvation period, but reached similar values as in the FC group only in Treatment S1 (Table 1, Fig. 3B). A comparison of biomass in newly moulted Zoea II larvae from FC, S1 and S3 showed significant differences, with lower values in S3 than in the other treatments.

The occurrence of successive larval moulting stages is shown in Table 2. In SC larvae, the moulting cycle was consistently arrested at the onset of the apolysis process (beginning of Stage $\mathrm{D}_{0}$ ). The delay in moulting described above for the S3 treatment is reflected here in the duration of the individual moulting stages, especially early premoult $\left(D_{0}\right)$. In the S5 treatment, some individuals showed signs of an incipient morphogenesis (Stage $\mathrm{D}_{1}$ ), but none of these reached ecdysis.

Food limitation also affected the lipid reserves stored in the digestive gland (Table 3 ). In the FC group, the lipid content remained high (VI $\geq 30 \%$ ) throughout the experiment (Fig. 4B). In SC larvae, by contrast, the lipid content decreased from Day 2
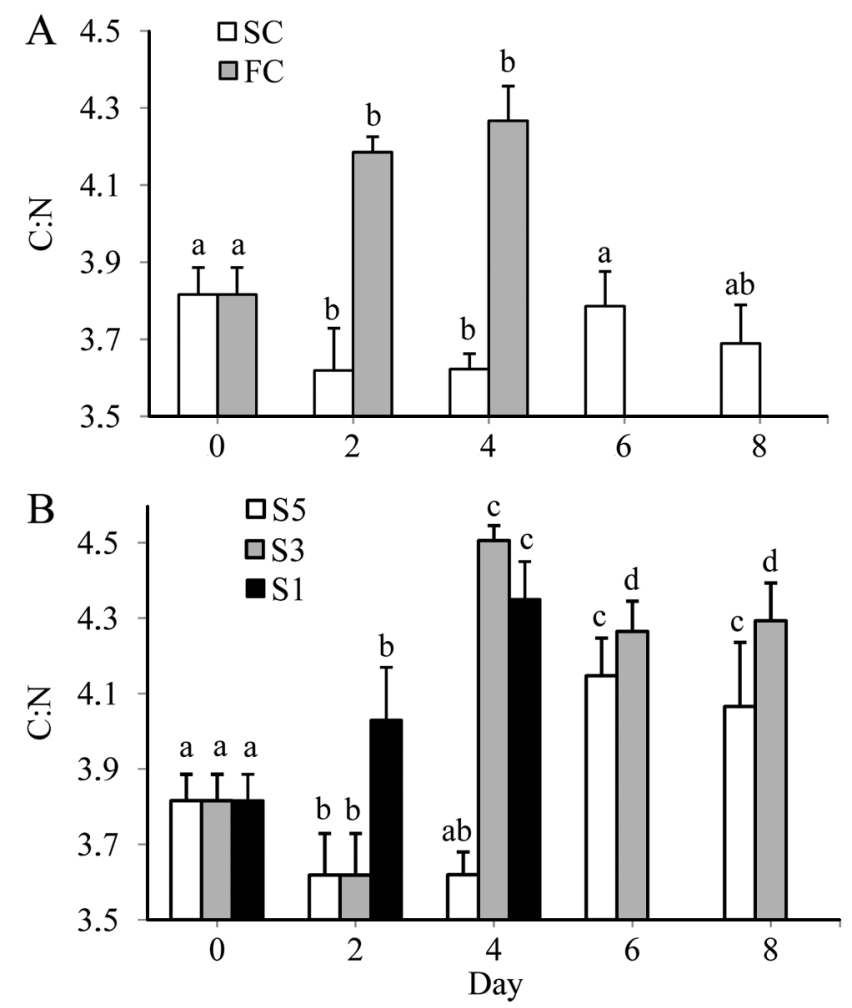

Fig. 3. Maja brachydactyla. Point-of-no-return experiment. $\mathrm{C}: \mathrm{N}$ ratio in (A) continuously starved or continuously fed control groups (SC, FC); (B) Treatments S1, S3, S5 (see Fig. 1); different lowercase letters indicate significant differences among days (SNK or Dunn's test) 
Table 1. Maja brachydactyla. Point-of-no-return experiment. Dry mass (DM), contents of carbon $(\mathrm{C})$, nitrogen $(\mathrm{N})$ and hydrogen $(\mathrm{H})\left(\right.$ all in $\mu \mathrm{g}$ ind..$^{-1}$ ) of Zoeae I and Zoeae II (the latter in bold). Treatments as in Fig. 1. Data are \pm SE. Different lowercase letters indicate significant differences among days (SNK or Dunn's test). Res. var.: response variable; gaps indicate not applicable

\begin{tabular}{|c|c|c|c|c|c|c|}
\hline $\begin{array}{l}\text { Res. } \\
\text { var. }\end{array}$ & Day & $\mathrm{FC}$ & S1 & $\begin{array}{c}\text { - Treatment } \\
\text { S3 }\end{array}$ & S5 & $\mathrm{SC}$ \\
\hline $\mathrm{DM}$ & $\begin{array}{l}0 \\
2 \\
4 \\
6 \\
8\end{array}$ & $\begin{array}{l}110 \pm 15.5^{\mathrm{a}} \\
129 \pm 4.90^{\mathrm{b}} \\
142 \pm 8.60^{\mathrm{b}} \\
\mathbf{1 6 1} \pm \mathbf{7 . 8 0 ^ { \mathbf { c } }}\end{array}$ & $\begin{array}{l}110 \pm 15.5^{\mathrm{a}} \\
123 \pm 6.90^{\mathrm{ab}} \\
135 \pm 8.70^{\mathrm{b}} \\
\mathbf{1 7 0} \pm \mathbf{2 0 . 9}^{\mathbf{c}}\end{array}$ & $\begin{aligned} 110 & \pm 15.5^{\mathrm{a}} \\
99.3 & \pm 6.15^{\mathrm{a}} \\
121 & \pm 4.40^{\mathrm{b}} \\
115 & \pm 6.00^{\mathrm{ab}} \\
119 & \pm 5.80^{\mathrm{b}} \\
\mathbf{1 3 8} & \pm \mathbf{1 3 . 1}^{\mathrm{c}}\end{aligned}$ & $\begin{aligned} 110 & \pm 15.5^{\mathrm{a}} \\
99.3 & \pm 6.15^{\mathrm{a}} \\
96.4 & \pm 3.43^{\mathrm{a}} \\
103 & \pm 1.02^{\mathrm{a}} \\
103 & \pm 4.90^{\mathrm{a}}\end{aligned}$ & $\begin{array}{r}110 \pm 15.5^{\mathrm{a}} \\
99.3 \pm 6.15^{\mathrm{a}} \\
96.4 \pm 3.43^{\mathrm{a}} \\
91.6 \pm 2.11^{\mathrm{b}} \\
85.0 \pm 2.42^{\mathrm{b}}\end{array}$ \\
\hline C & $\begin{array}{l}0 \\
2 \\
4 \\
6 \\
8\end{array}$ & $\begin{array}{l}35.5 \pm 0.85^{\mathrm{a}} \\
46.0 \pm 1.50^{\mathrm{ab}} \\
51.2 \pm 7.05^{\mathrm{b}} \\
\mathbf{5 8 . 6} \pm \mathbf{3 . 8 8}^{\mathbf{b}}\end{array}$ & $\begin{array}{l}35.5 \pm 0.85^{\mathrm{a}} \\
40.6 \pm 3.12^{\mathrm{ab}} \\
50.7 \pm 3.70^{\mathrm{b}} \\
\mathbf{6 1 . 2} \pm \mathbf{9 . 8 0}^{\mathbf{b}}\end{array}$ & $\begin{array}{l}35.5 \pm 0.85^{\mathrm{a}} \\
29.3 \pm 1.63^{\mathrm{b}} \\
40.1 \pm 1.68^{\mathrm{b}} \\
38.9 \pm 3.04^{\mathrm{b}} \\
39.5 \pm 2.88^{\mathrm{b}} \\
\mathbf{4 8 . 3} \pm \mathbf{4 . 7 4}^{\mathbf{c}}\end{array}$ & $\begin{array}{l}35.5 \pm 0.85^{\mathrm{a}} \\
29.3 \pm 1.63^{\mathrm{b}} \\
26.9 \pm 0.79^{\mathrm{c}} \\
29.8 \pm 1.24^{\mathrm{b}} \\
30.7 \pm 2.64^{\mathrm{b}}\end{array}$ & $\begin{array}{l}35.5 \pm 0.85^{\mathrm{a}} \\
29.3 \pm 1.63^{\mathrm{b}} \\
26.9 \pm 0.79^{\mathrm{c}} \\
24.5 \pm 0.47^{\mathrm{d}} \\
21.7 \pm 0.39^{\mathrm{d}}\end{array}$ \\
\hline $\mathrm{N}$ & $\begin{array}{l}0 \\
2 \\
4 \\
6 \\
8\end{array}$ & $\begin{array}{l}9.35 \pm 0.22^{\mathrm{a}} \\
11.0 \pm 0.30^{\mathrm{ab}} \\
12.0 \pm 1.40^{\mathrm{b}} \\
\mathbf{1 3 . 3} \pm \mathbf{0 . 5 8}^{\mathbf{b}}\end{array}$ & $\begin{array}{l}9.35 \pm 0.22^{\mathrm{a}} \\
10.0 \pm 0.50^{\mathrm{ab}} \\
11.6 \pm 0.66^{\mathrm{b}} \\
\mathbf{1 3 . 4} \pm \mathbf{1 . 5 0}^{\mathbf{b}}\end{array}$ & $\begin{array}{l}9.35 \pm 0.22^{\mathrm{a}} \\
8.10 \pm 0.40^{\mathrm{b}} \\
8.90 \pm 0.28^{\mathrm{ab}} \\
9.12 \pm 0.60^{\mathrm{a}} \\
9.20 \pm 0.39^{\mathrm{a}} \\
\mathbf{1 1 . 0} \pm \mathbf{0 . 8 0}^{\mathbf{c}}\end{array}$ & $\begin{array}{l}9.35 \pm 0.22^{\mathrm{a}} \\
8.10 \pm 0.40^{\mathrm{b}} \\
7.43 \pm 0.18^{\mathrm{c}} \\
7.20 \pm 0.16^{\mathrm{c}} \\
7.57 \pm 0.55^{\mathrm{c}}\end{array}$ & $\begin{array}{l}9.35 \pm 0.22^{\mathrm{a}} \\
8.10 \pm 0.40^{\mathrm{b}} \\
7.43 \pm 0.18^{\mathrm{c}} \\
6.47 \pm 0.16^{\mathrm{d}} \\
5.88 \pm 0.18^{\mathrm{d}}\end{array}$ \\
\hline $\mathrm{H}$ & $\begin{array}{l}0 \\
2 \\
4 \\
6 \\
8\end{array}$ & $\begin{array}{r}6.33 \pm 0.31^{\mathrm{a}} \\
8.0 \pm 0.22^{\mathrm{b}} \\
7.05 \pm 8.70^{\mathrm{b}} \\
\mathbf{9 . 9 6} \pm \mathbf{0 . 5 0}^{\mathbf{c}}\end{array}$ & $\begin{array}{l}6.33 \pm 0.31^{\mathrm{a}} \\
7.20 \pm 0.46^{\mathrm{a}} \\
8.90 \pm 0.54^{\mathrm{b}} \\
\mathbf{1 0 . 2} \pm \mathbf{1 . 3 5}^{\mathbf{c}}\end{array}$ & $\begin{array}{l}6.33 \pm 0.31^{\mathrm{a}} \\
5.65 \pm 0.19^{\mathrm{ab}} \\
7.30 \pm 0.21^{\mathrm{b}} \\
6.90 \pm 0.37^{\mathrm{b}} \\
7.00 \pm 0.40^{\mathrm{b}} \\
\mathbf{8 . 3 4} \pm \mathbf{0 . 6 2}^{\mathbf{c}}\end{array}$ & $\begin{array}{l}6.33 \pm 0.31^{\mathrm{a}} \\
5.65 \pm 0.19^{\mathrm{ab}} \\
5.38 \pm 0.11^{\mathrm{ab}} \\
5.78 \pm 0.17^{\mathrm{a}} \\
6.38 \pm 0.46^{\mathrm{b}}\end{array}$ & $\begin{array}{l}6.33 \pm 0.31^{\mathrm{a}} \\
5.65 \pm 0.19^{\mathrm{ab}} \\
5.38 \pm 0.11^{\mathrm{ab}} \\
5.12 \pm 0.10^{\mathrm{b}} \\
4.69 \pm 0.09^{\mathrm{b}}\end{array}$ \\
\hline
\end{tabular}

Table 2. Maja brachydactyla. Moulting stages in the pointof-no-return experiment. Treatments as in Fig. 1. Stage descriptions: A-B: spongy epidermis; C: condensation of the epidermal tissues; $\mathrm{D}_{0}$ : apolysis; $\mathrm{D}_{1}$ : setagenesis; $\mathrm{D}_{2}$ : appearance of new cuticle; E: ecdysis

\begin{tabular}{|lcccccc|}
\hline \multirow{2}{*}{ Day } & \multicolumn{7}{c|}{ Treatment } \\
\cline { 2 - 7 } & $\mathrm{FC}$ & $\mathrm{S} 1$ & $\mathrm{~S} 3$ & $\mathrm{~S} 5$ & $\mathrm{~S} 7$ & $\mathrm{SC}$ \\
\hline 0 & $\mathrm{~A}-\mathrm{C}$ & $\mathrm{A}-\mathrm{C}$ & $\mathrm{A}-\mathrm{C}$ & $\mathrm{A}-\mathrm{C}$ & $\mathrm{A}-\mathrm{C}$ & $\mathrm{A}-\mathrm{C}$ \\
2 & $\mathrm{D}_{0}$ & $\mathrm{D}_{0}$ & $\mathrm{D}_{0}$ & $\mathrm{D}_{0}$ & $\mathrm{D}_{0}$ & $\mathrm{D}_{0}$ \\
4 & $\mathrm{D}_{1}-\mathrm{D}_{2}$ & $\mathrm{D}_{1}-\mathrm{D}_{2}$ & $\mathrm{D}_{0}$ & $\mathrm{D}_{0}$ & $\mathrm{D}_{0}$ & $\mathrm{D}_{0}$ \\
6 & $\mathrm{E}$ & $\mathrm{E}$ & $\mathrm{D}_{0}-\mathrm{D}_{2}$ & $\mathrm{D}_{0}$ & $\mathrm{D}_{0}$ & $\mathrm{D}_{0}$ \\
8 & & & $\mathrm{D}_{0}-\mathrm{E}$ & $\mathrm{D}_{0}$ & $\mathrm{D}_{0}$ & $\mathrm{D}_{0}$ \\
10 & & & $\mathrm{E}$ & $\mathrm{D}_{1}$ & $\mathrm{D}_{0}$ & $\mathrm{D}_{0}$ \\
\hline
\end{tabular}

rapidly to VI values $<10 \%$, and to $5 \%$ after Day 4 (Fig. 4A,B). Feeding after periods of initial starvation of 1 to $5 \mathrm{~d}$ (S1 to S5) always resulted in a reestablishment of the lipid contents (Fig. 4C,D). In the S7 treatment, the lipid content increased only slightly, without reaching the level of the other treatments (Table 3).

Another effect of food limitation was observed in the activities of digestive enzymes (Table 4). In the FC group, protease and amylase activity increased significantly throughout the Zoea I moult cycle. In larvae kept under SC conditions, by comparison, the enzymatic activities decreased within the first $8 \mathrm{~d}$. A comparison of enzyme activities among Zoeae II obtained from FC, S1 and S3 treatments indicated significant differences with a lower value for S3 compared to the other groups (ANOVA, p < 0.05).

\section{PRS experiment}

As in the PNR experiment, SC larvae did not moult to Zoeae II. In larvae fed only during the first day, mortality was $86 \%$, while it was $<50 \%$ in larvae that were fed for 2 or more days (Fig. 2B). PRS Pno $_{1}$ was $1.9 \mathrm{~d}$. The number of days with initial food availability also had a significant effect on the duration of the Zoea I moulting cycle (ANOVA, p < 0.05; Fig. 2B).

In the FC group, Zoeae I biomass and the $\mathrm{C}: \mathrm{N}$ ratio increased from hatching to moulting to Zoeae II, similar to the FC in the PNR experiment (Table 5; Fig. 5A). In SC larvae, by contrast, biomass decreased

Table 3. Maja brachydactyla. Point-of-no-return experiment. Vacuole index (VI, \%) measured in the digestive glands of Zoeae I and Zoeae II (the latter in bold). Treatments as in Fig. 1. Data are \pm SE. Different lowercase letters indicate significant differences among days (SNK or Dunn's test)

\begin{tabular}{|c|c|c|c|c|c|c|}
\hline \multirow{2}{*}{ Day } & \multicolumn{6}{|c|}{ - Treatment } \\
\hline & $\mathrm{SC}$ & S7 & S5 & S3 & S1 & $\mathrm{FC}$ \\
\hline 0 & $32.90 \pm 8.32^{\mathrm{a}}$ & $32.90 \pm 8.32^{\mathrm{a}}$ & $32.90 \pm 8.32^{\mathrm{a}}$ & $32.90 \pm 8.32^{\mathrm{a}}$ & $32.90 \pm 8.32^{\mathrm{ab}}$ & $32.90 \pm 8.32^{\mathrm{a}}$ \\
\hline 2 & $12.10 \pm 4.60^{\mathrm{a}}$ & $12.10 \pm 4.60^{\mathrm{ab}}$ & $12.20 \pm 4.60^{\mathrm{ab}}$ & $9.4 \pm 3.60^{\mathrm{b}}$ & $23.30 \pm 5.61^{\mathrm{a}}$ & $33.30 \pm 7.61^{\mathrm{a}}$ \\
\hline 4 & $2.11 \pm 2.20^{\mathrm{ab}}$ & $2.11 \pm 2.20^{\mathrm{b}}$ & $2.11 \pm 2.20^{\mathrm{b}}$ & $34.80 \pm 7.25^{\mathrm{a}}$ & $45.60 \pm 19.20^{\mathrm{ab}}$ & $37.30 \pm 7.32^{\mathrm{a}}$ \\
\hline 6 & $2.90 \pm 2.30^{\mathrm{ab}}$ & $2.90 \pm 2.30^{b}$ & $24.50 \pm 2.43^{\mathrm{a}}$ & $31.10 \pm 4.83^{\mathrm{a}}$ & $53.38 \pm 5.55^{b}$ & $39.80 \pm 9.30^{a}$ \\
\hline 8 & $1.20 \pm 1.32^{\mathrm{b}}$ & $13.20 \pm 9.60^{b}$ & $23.40 \pm 13.1^{\mathrm{ab}}$ & $39.50 \pm 7.51^{\mathrm{a}}$ & & \\
\hline
\end{tabular}



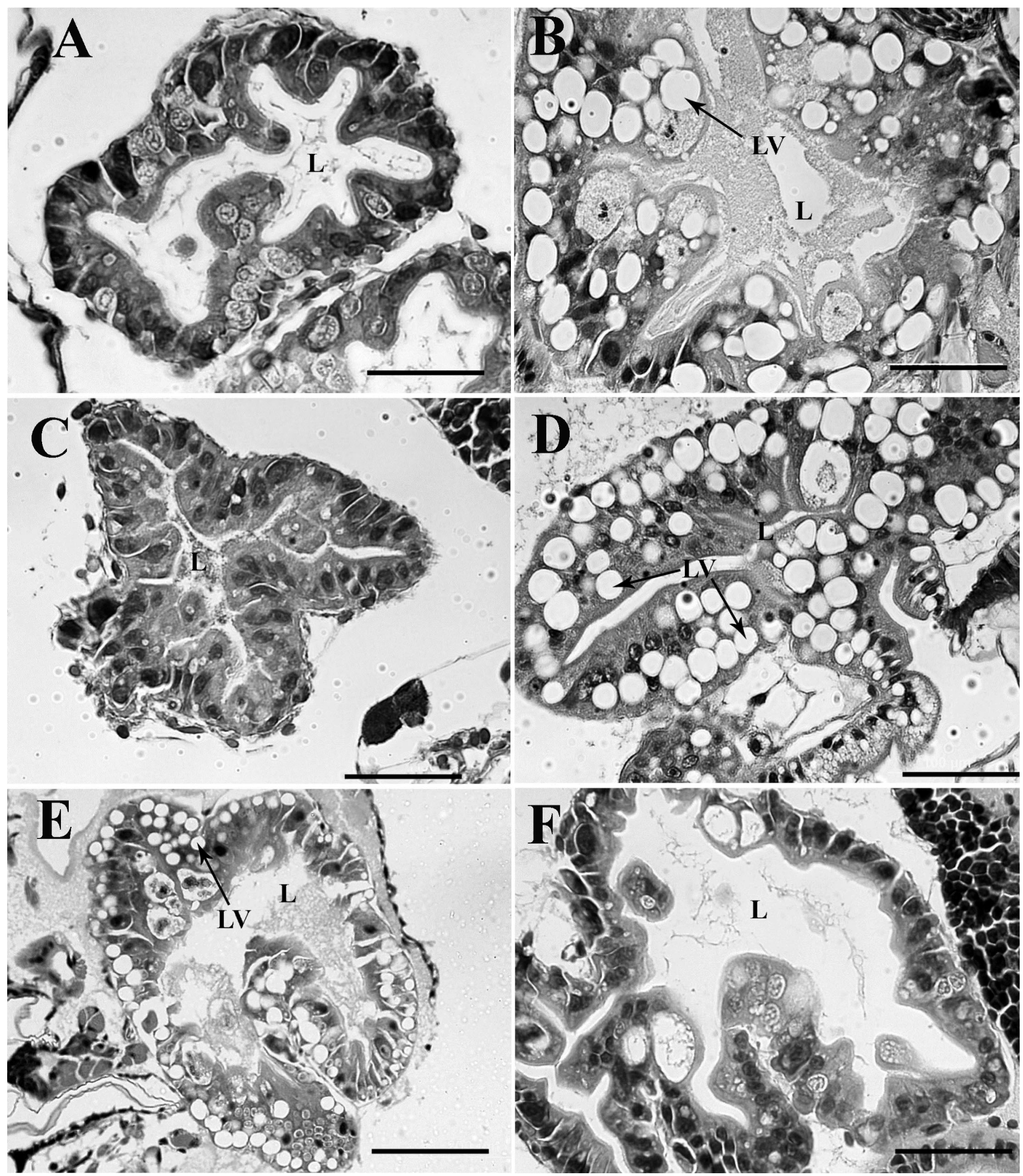

Fig. 4. Maja brachydactyla. Histological sections of the digestive gland. (A) Point-of-no-return (PNR) experiment, continuously starved control group (SC), Day 4; (B) PNR experiment; continuously fed control group (FC), Day 4; (C) PNR experiment: Treatment S5 (5 d of starvation), Day 4; (D) PNR experiment: Treatment S5, Day 8; (E) point-of-reserve-saturation (PRS) experiment: Treatment F2 (2 d of feeding), Day 2; (F) PRS experiment: Treatment F2, Day 3. L: lumen; LV: lipid vacuole. Scale bars $=50 \mu \mathrm{m}$ 
Table 4. Maja brachydactyla. Total amylase and protease activities (IU ind ${ }^{-1}$ ) in different treatments (point-of-no-return experiment) in Zoeae I and Zoeae II (the latter in bold). Treatments as in Fig. 1. Data are \pm SE. Different lowercase letters indicate significant differences among days (SNK or Dunn's test)

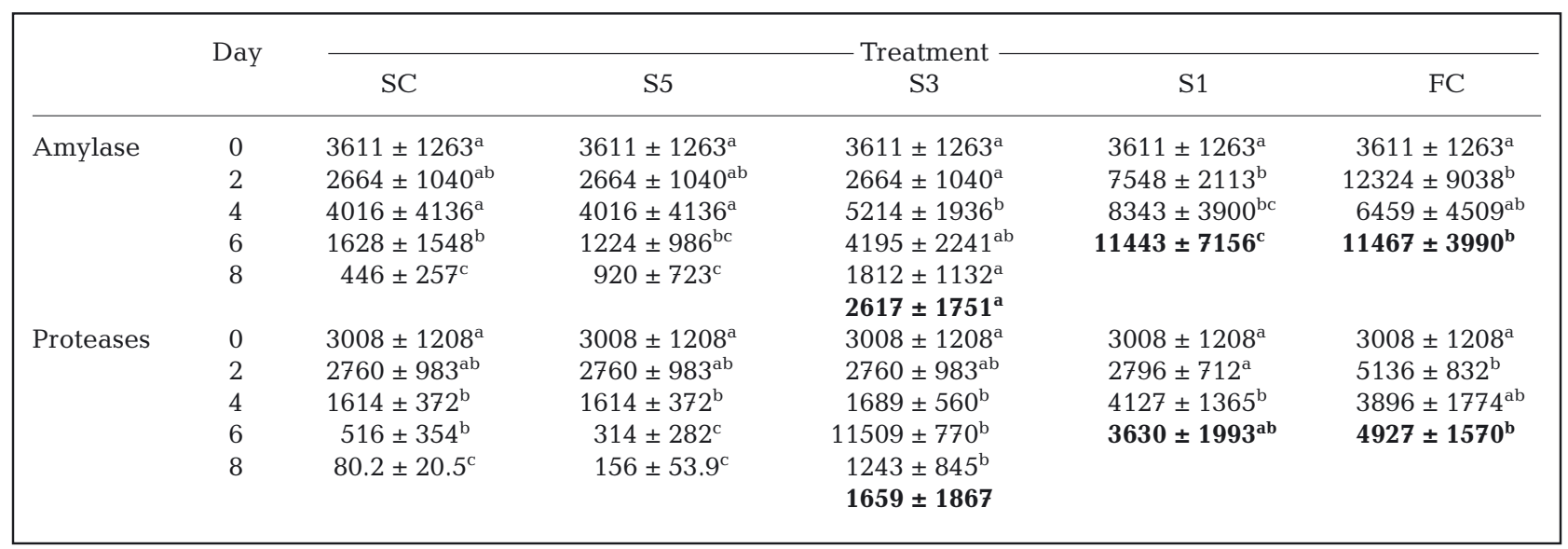

Table 5. Maja brachydactyla. Point-of-reserve-saturation experiment. Dry mass (DM), contents of carbon (C), nitrogen (N) and hydrogen $(\mathrm{H})$ (all in $\mu \mathrm{g}$ ind.$^{-1}$ ) of Zoeae I and Zoeae II (the latter in bold). Treatments as in Fig. 1. Data are \pm SE. Different lowercase letters indicate significant differences among days (after SNK or Dunn's test); (-): missing data; gaps: not applicable

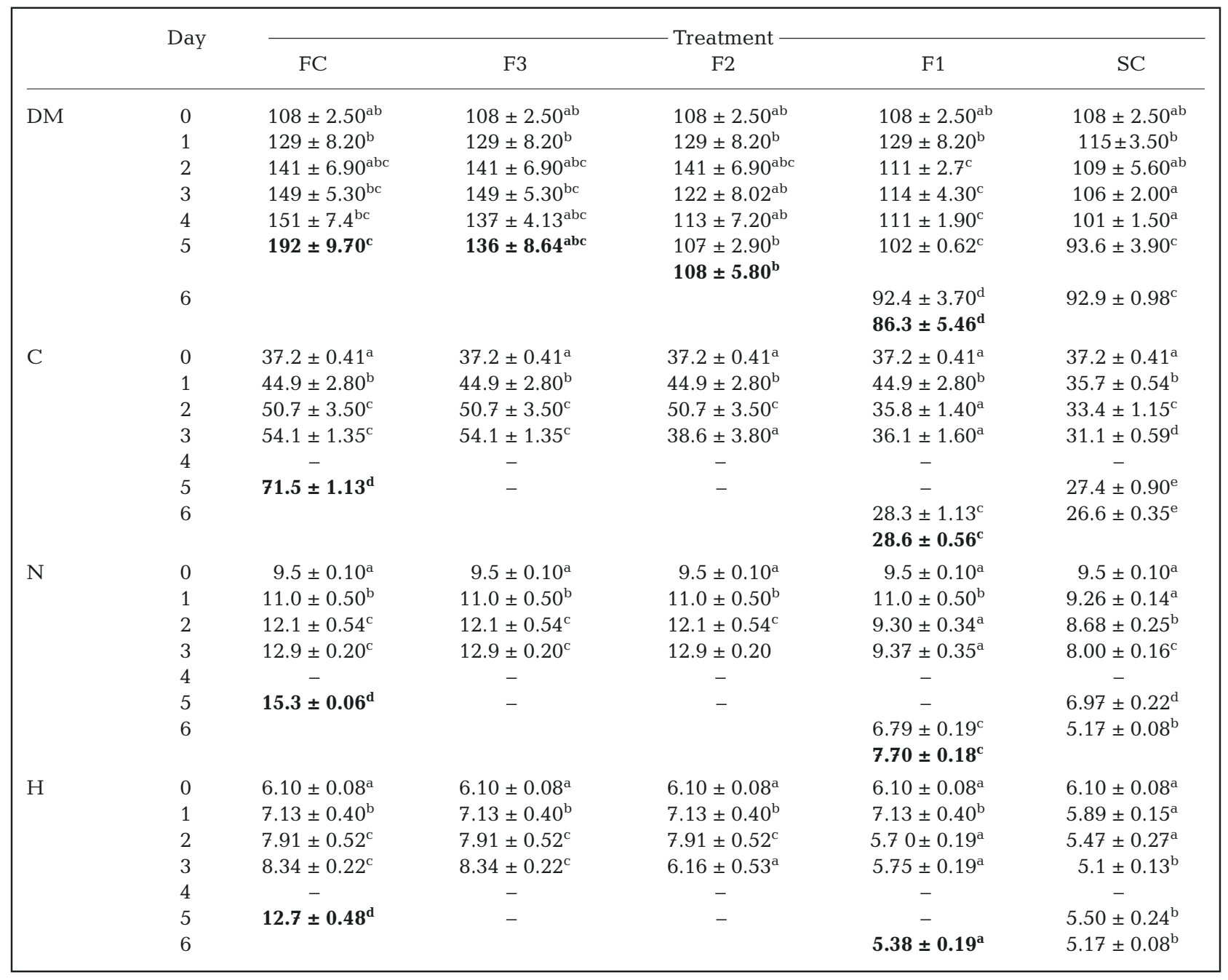



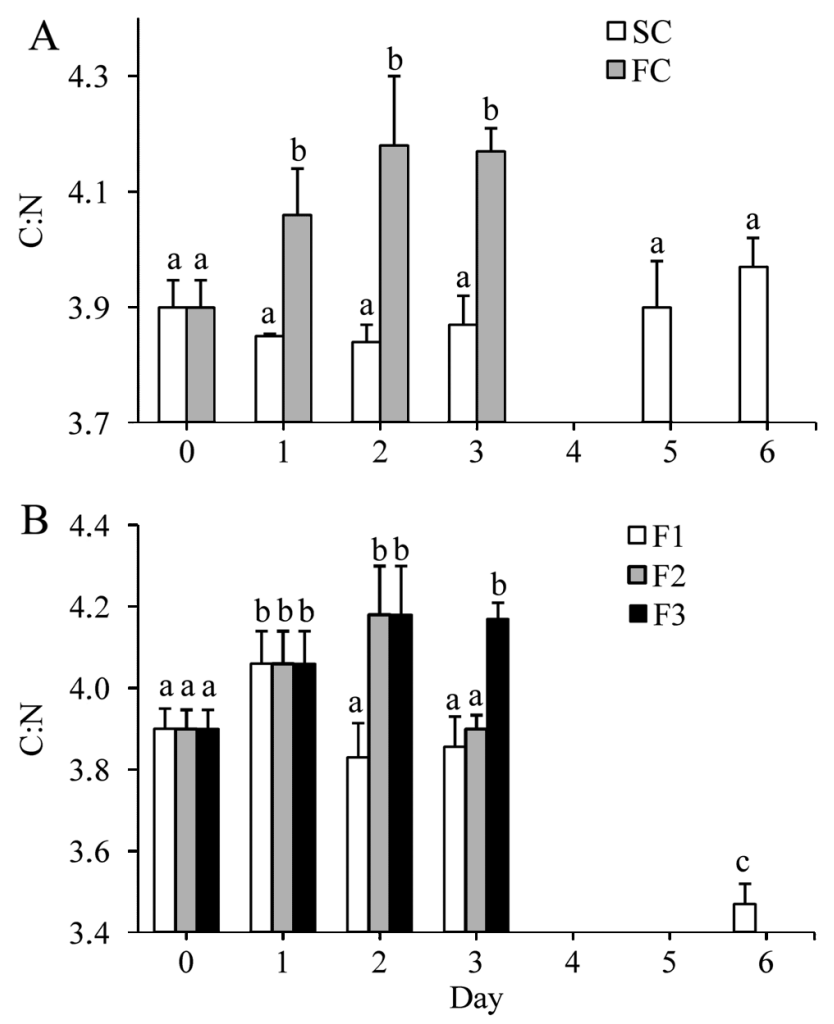

Fig. 5. Maja brachydactyla. Point-of-reserve-saturation experiment. C:N ratio in (A) continuously starved or continuously fed control groups (SC, FC); (B) Treatments F1 to F3 (see Fig. 1); different lowercase letters indicate significant differences among days (SNK or Dunn's test)

continuously. The C:N mass ratio varied only slightly, following a similar pattern to that described for the PNR experiment (Fig. 5A). In the F1 and F2 treatments, biomass and the $\mathrm{C}: \mathrm{N}$ ratio decreased during the final period of starvation (Table 5, Fig. 5B). A comparison of biomass and C:N in Zoeae II obtained from different treatments indicated significant differ- ences, with lower values in F1 and F2 compared to FC treatments. The DM of newly moulted Zoeae II was linearly correlated with the duration of the feeding periods in the preceding Zoea I moulting cycle (Fig. 6A), indicating that differential growth in Zoeae I translated to different biomass in the subsequent larval stage.

The occurrence of the successive moulting stages is shown in Table 6. Under SC conditions, the moulting cycle was again arrested at the beginning of apolysis (stage $D_{0}$ ), while the larvae in all other treatments were able to reach Stage E (ecdysis to Zoea II). In Treatments F1 and F2, the duration of the moulting stages increased, especially in the premoult stages, D (Table 6). The patterns in the FC and SC control groups were similar to those obtained in the PNR experiment.

Under FC conditions, the lipid content in the hepatopancreas remained high (VI $\geq 30 \%$ ), whereas it declined rapidly in starved larvae (Table 7, Fig. 4E,F). The PRS experiment also confirms the effects of food limitation on digestive enzyme activities as shown above (Tables $4 \& 8$ ), with enzymatic activities decreasing during starvation periods. Like the DM values per larva, amylase and protease activities measured in newly moulted Zoeae II were also linearly correlated with the duration of the feeding periods in Zoeae I (Table 8, Fig. 6B,C), again showing carryover effects of larval condition in the previous stage.

\section{DISCUSSION}

Using an experimental approach with gradational periods of addition or withdrawal of food (PNR and PRS experiments; Anger \& Dawirs 1981) in combination with high-resolution measurements of chemical
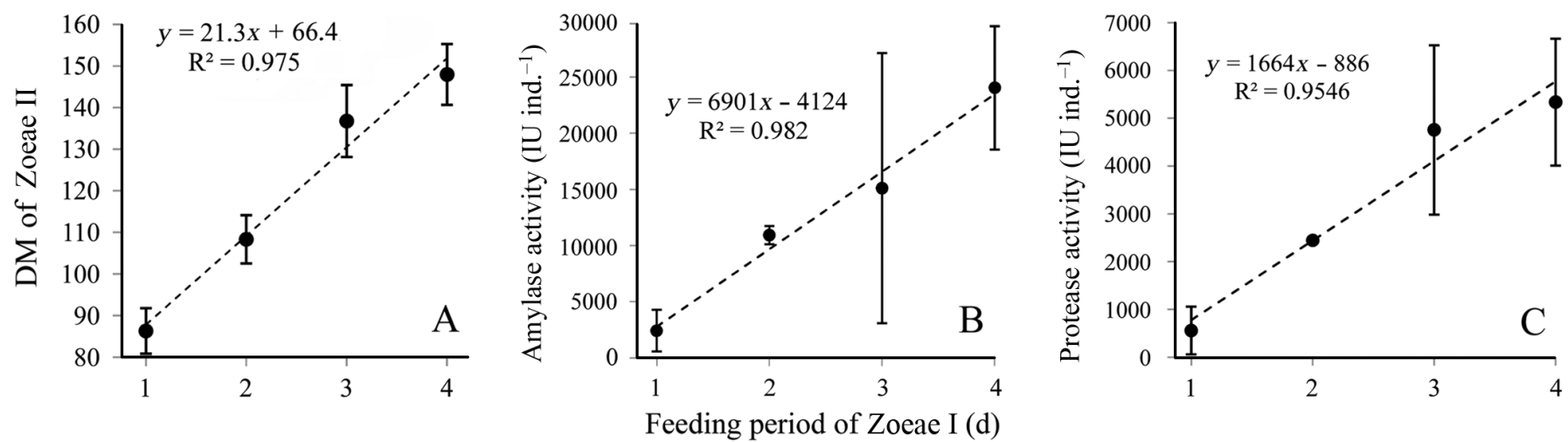

Fig. 6. Maja brachydactyla. Point-of-reserve-saturation experiment. Relationships between the number of days of initial feeding in the Zoea I stage and (A) dry mass (DM) of newly moulted Zoea II larvae, (B) amylase activity in Zoeae II, (C) protease activity in Zoeae II 
Table 6. Maja brachydactyla. Moulting stages in the pointof-reserve-saturation experiment. Treatments as in Fig. 1. Stage descriptions as in Table 2

\begin{tabular}{|lcccccc|}
\hline \multirow{2}{*}{ Day } & \multicolumn{7}{c}{ Treatment } \\
\cline { 2 - 7 } & $\mathrm{FC}$ & $\mathrm{F} 4$ & $\mathrm{~F} 3$ & $\mathrm{~F} 2$ & $\mathrm{~F} 1$ & $\mathrm{SC}$ \\
\hline 0 & $\mathrm{~A}-\mathrm{C}$ & $\mathrm{A}-\mathrm{C}$ & $\mathrm{A}-\mathrm{C}$ & $\mathrm{A}-\mathrm{C}$ & $\mathrm{A}-\mathrm{C}$ & $\mathrm{A}-\mathrm{C}$ \\
2 & $\mathrm{D}_{0}$ & $\mathrm{D}_{0}$ & $\mathrm{D}_{0}$ & $\mathrm{D}_{0}$ & $\mathrm{D}_{0}$ & $\mathrm{D}_{0}$ \\
4 & $\mathrm{D}_{1}-\mathrm{D}_{2}$ & $\mathrm{D}_{1}-\mathrm{D}_{2}$ & $\mathrm{D}_{1}-\mathrm{D}_{2}$ & $\mathrm{D}_{1}-\mathrm{D}_{2}$ & $\mathrm{D}_{1}-\mathrm{D}_{2}$ & $\mathrm{D}_{0}$ \\
6 & $\mathrm{E}$ & $\mathrm{E}$ & $\mathrm{D}_{2}-\mathrm{E}$ & $\mathrm{D}_{2}$ & $\mathrm{D}_{0}-\mathrm{D}_{2}$ & $\mathrm{D}_{0}$ \\
8 & & & $\mathrm{E}$ & $\mathrm{D}_{2}-\mathrm{E}$ & $\mathrm{D}_{2}-\mathrm{E}$ & $\mathrm{D}_{0}$ \\
10 & & & & & $\mathrm{E}$ & $\mathrm{D}_{0}$ \\
& & & & & & \\
\hline
\end{tabular}

and physiological parameters, our study shows conspicuous larval response patterns within the moulting cycle of the first zoeal stage of the commercially exploited spider crab Maja brachydactyla. Similar to closely related species such as the majid Hyas araneus (Anger \& Dawirs 1981, 1982, Anger et al. 1989), and consistent with recent observations in $M$. brachydactyla (Andrés et al. 2008, Rotllant et al. 2010), the first-stage larvae are obligatorily planktotrophic, requiring food in order to successfully reach the second zoeal stage. Continuously fed zoeae showed significant growth in total DM and organically bound elements (CHN) per larva, an increase of the $\mathrm{C}: \mathrm{N}$ ratio (indicating lipid accumulation), as well as an accumulation of fat vacuoles in the hepatopancreas, and an increase in the activities of major digestive enzymes (total protease and amylase). Continuously starved larvae, by contrast, showed opposite trends in all of these parameters, and they eventually died (after a maximum of $11 \mathrm{~d}$ ), without moulting to

Table 7. Maja brachydactyla. Point-of-reserve-saturation experiment. Vacuole index (VI, \%) measured in the digestive glands of Zoeae I and Zoeae II (the latter in bold). Treatments as in Fig. 1. Data are \pm SE. Different lowercase letters indicate significant differences among days (SNK or Dunn's test)

\begin{tabular}{|c|c|c|c|c|c|}
\hline \multirow{2}{*}{ Day } & \multicolumn{5}{|c|}{ - Treatment } \\
\hline & $\mathrm{FC}$ & F3 & F2 & $\mathrm{F} 1$ & $\mathrm{SC}$ \\
\hline 0 & $12.2 \pm 5.80^{\mathrm{a}}$ & $12.2 \pm 5.80^{\mathrm{a}}$ & $12.2 \pm 5.80^{\mathrm{a}}$ & $12.2 \pm 5.80^{\mathrm{ab}}$ & $12.2 \pm 5.80^{\mathrm{a}}$ \\
\hline 1 & $28.1 \pm 8.31^{b}$ & $28.1 \pm 8.31^{b}$ & $28.1 \pm 8.31^{b}$ & $28.1 \pm 8.31^{\mathrm{a}}$ & $8.41 \pm 10.2^{\mathrm{a}}$ \\
\hline 2 & $24.4 \pm 5.11^{\mathrm{ab}}$ & $24.4 \pm 5.11^{\mathrm{ab}}$ & $24.4 \pm 5.11^{b}$ & $12.2 \pm 2.12^{\mathrm{ab}}$ & $4.72 \pm 2.70^{\mathrm{a}}$ \\
\hline 3 & $28.5 \pm 6.01^{\mathrm{b}}$ & $24.6 \pm 2.80^{\mathrm{b}}$ & $6.30 \pm 1.30^{\mathrm{a}}$ & $8.02 \pm 3.80^{\mathrm{ab}}$ & $2.04 \pm 0.10^{\mathrm{a}}$ \\
\hline 4 & $31.5 \pm 7.43^{\mathrm{b}}$ & $19.1 \pm 7.30^{\mathrm{ab}}$ & $4.50 \pm 2.50^{\mathrm{a}}$ & $6.01 \pm 2.55^{\mathrm{ab}}$ & $3.70 \pm 3.21^{\mathrm{a}}$ \\
\hline 5 & $27.0 \pm 7.80^{\mathrm{ab}}$ & $25.3 \pm 6.35^{\mathrm{ab}}$ & $3.30 \pm 3.10^{\mathrm{a}}$ & $1.10 \pm 1.23^{\mathrm{b}}$ & $1.83 \pm 1.50^{\mathrm{a}}$ \\
\hline 6 & & & $7.2 \pm 2.82^{\mathrm{a}}$ & $3.01 \pm 1.40^{\mathrm{b}}$ & $1.25 \pm 1.10^{\mathrm{a}}$ \\
\hline & & & & $1.40 \pm 1.71^{b}$ & \\
\hline 7 & & & & $1.60 \pm 1.52^{\mathrm{b}}$ & $1.37 \pm 1.10^{\mathrm{a}}$ \\
\hline 8 & & & & & $0.50 \pm 2.20^{\mathrm{a}}$ \\
\hline
\end{tabular}

Table 8. Maja brachydactyla. Total amylase and proteases activities (IU ind. ${ }^{-1}$ ) in different treatments (point-of-reserve-saturation experiment) in Zoeae I and Zoeae II (the latter in bold). Treatments as in Fig. 1. Data are \pm SE. Different lowercase letters indicate significant differences among days (after SNK test or Dunn's test)

\begin{tabular}{|c|c|c|c|c|c|c|}
\hline & \multirow{2}{*}{ Day } & \multicolumn{5}{|c|}{ - Treatment } \\
\hline & & $\mathrm{FC}$ & F3 & $\mathrm{F} 2$ & F1 & $\mathrm{SC}$ \\
\hline \multirow[t]{8}{*}{ Amylase } & 0 & $5627 \pm 3378^{a}$ & $5627 \pm 3378^{a}$ & $5627 \pm 3378^{a}$ & $5627 \pm 3378^{a}$ & $5627 \pm 3378^{a}$ \\
\hline & 1 & $16917 \pm 9097^{\mathrm{b}}$ & $16917 \pm 9097^{\mathrm{b}}$ & $16917 \pm 9097^{b}$ & $12737 \pm 6236^{\mathrm{b}}$ & $4719 \pm 2740^{\mathrm{a}}$ \\
\hline & 2 & $29297 \pm 14385^{\mathrm{c}}$ & $29297 \pm 14385^{\mathrm{c}}$ & $29297 \pm 14385^{\mathrm{c}}$ & $10237 \pm 6618^{\mathrm{bc}}$ & $6564 \pm 5486^{a}$ \\
\hline & 3 & $26396 \pm 13976^{\mathrm{bc}}$ & $26396 \pm 13976^{b c}$ & $12922 \pm 8354^{\mathrm{bd}}$ & $11494 \pm 9209^{\mathrm{ac}}$ & $3635 \pm 2481^{\mathrm{ab}}$ \\
\hline & 4 & $29031 \pm 15178^{c}$ & $13469 \pm 4526^{\mathrm{b}}$ & $15262 \pm 10395^{\mathrm{bd}}$ & $5677 \pm 4714^{\mathrm{a}}$ & $3922 \pm 3833^{\mathrm{ab}}$ \\
\hline & 5 & $24044 \pm 15486^{b c}$ & $15114 \pm 12023^{b}$ & $8114 \pm 3038^{\mathrm{ad}}$ & $2293 \pm 1789^{a}$ & $3378 \pm 3216^{b}$ \\
\hline & & & & $10406 \pm 8807^{\mathrm{ad}}$ & & \\
\hline & 6 & & & & $2433 \pm 1857^{a}$ & $1828 \pm 1083^{\mathrm{b}}$ \\
\hline \multirow[t]{8}{*}{ Proteases } & 0 & $3551 \pm 1147^{a}$ & $3551 \pm 1147^{a}$ & $3551 \pm 1147^{a}$ & $3551 \pm 1147^{a}$ & $3551 \pm 1147^{a}$ \\
\hline & 1 & $3386 \pm 1412^{\mathrm{a}}$ & $3386 \pm 1412^{\mathrm{a}}$ & $3386 \pm 1412^{\mathrm{a}}$ & $3386 \pm 1412^{\mathrm{a}}$ & $3949 \pm 1651^{\mathrm{a}}$ \\
\hline & 2 & $5123 \pm 1182^{\mathrm{bc}}$ & $5123 \pm 1182^{b}$ & $5123 \pm 1182^{b}$ & $3167 \pm 1598^{a}$ & $2741 \pm 1208^{a}$ \\
\hline & 3 & $5175 \pm 1483^{\mathrm{bc}}$ & $5175 \pm 1483^{b}$ & $3020 \pm 1662^{\mathrm{ac}}$ & $3239 \pm 1377^{a}$ & $1389 \pm 819^{b}$ \\
\hline & 4 & $4224 \pm 1993^{\mathrm{ab}}$ & $4909 \pm 1736^{b}$ & $3473 \pm 1406^{\mathrm{ac}}$ & $3083 \pm 1253^{a}$ & $1308 \pm 636^{b}$ \\
\hline & 5 & $5338 \pm 1328^{c}$ & $4757 \pm 1773^{b}$ & $2446 \pm 1134^{\mathrm{c}}$ & $1177 \pm 1171^{b}$ & $1239 \pm 778^{b}$ \\
\hline & & & & $3519 \pm 1700^{a}$ & & \\
\hline & 6 & & & & $559 \pm 601^{b}$ & $826 \pm 571^{b}$ \\
\hline
\end{tabular}


the Zoea II stage (cf. Rotllant et al. 2010). These general patterns of response to feeding and starvation, respectively, provide various quantitative and qualitative criteria for an evaluation of the physiological condition of larvae developing under intermediate or unknown nutritional situations.

Temporary or local occurrence of poor nutritional conditions is considered one of the key factors determining larval survival in the plankton (Morgan 1995, Giménez \& Anger 2005). While experimental conditions of both ad libitum feeding or complete absence of food represent extreme scenarios that may have little if any ecological relevance in natural habitats, they define the end points (maximum and minimum, respectively) of a relative scale of larval survival, development, growth and physiological responses to food limitation. In this context, PNR and PRS experiments are useful tools for the study of the nutritional needs or vulnerability of decapod crustacean larvae.

Congruent with the results of numerous previous studies with larvae of various other decapod groups (e.g. Dawirs 1984, Staton \& Sulkin 1991, Paschke et al. 2004, Gebauer et al. 2010), our experiments demonstrate that initial periods of food limitation beginning soon after hatching are much more critical than a later occurrence of famine. Besides the timing, the duration of such periods is also very important. While a single day of initial starvation and subsequent feeding did not cause irreversible damage affecting larval survival or development in comparison to a continuously fed control group (cf. S1 versus

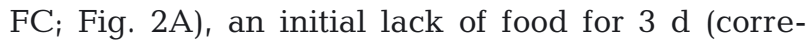
sponding to $>50 \%$ of the moult-cycle duration of fed larvae) caused high mortality, similar to that in a continuously starved control group. This PNR effect reflects irreversible structural or functional damage, most probably in the R-cells of the hepatopancreas (Storch \& Anger 1983, Anger et al. 1985), which may be considered a 'monitor organ' for assessments of the nutritional condition of crustaceans (see Vogt et al. 1985 and references therein). Although the present study showed that a successful capture of prey, digestion of food, and eventually, even a restoration of previously degraded lipid reserves in the hepatopancreas may still be possible after extended periods of starvation, some metabolic disorder seems to occur, preventing an efficient utilization of those energy reserves accumulated after the PNR.

In PRS experiments, only $2 \mathrm{~d}$ of initial feeding $(<30 \%$ of the moult-cycle duration), followed by complete lack of food for the remaining $>70 \%$ of the moult cycle, may allow for similar rates of survival and development to the Zoea II stage as in a conti- nuously fed control group (F2 versus FC; Fig. 2B). This again shows the importance of the timing (early versus late) of starvation periods. Microscopic examination of the larval moulting cycle in our study demonstrated that the PRS was reached at the transition between stages $C$ and $D_{0}$, when the apolysis of epidermal tissues from the old cuticle begins. This confirms the ' $\mathrm{D}_{0}$ threshold' (Anger 1987) as a critical point, after which a decapod larva becomes in principle independent from food for the rest of the moulting cycle.

When the biomass accumulated during an early period of larval feeding and growth is considered at the time of the $\mathrm{PRS}_{50}$, one can see that Zoeae I of Maja brachydactyla have reached about 70 to $80 \%$ of the maximum DM that continuously fed sibling larvae would show at their moult to the Zoea II stage, although the developmental period from hatching to the PRS corresponds to only about $50 \%$ of total moult-cycle duration (present study; cf. Rotllant et al. 2010). This apparent discrepancy between a relatively short time span and high biomass growth is normally due to maximum instantaneous growth rates during the postmoult and intermoult stages, which are followed by lower accumulation rates in premoult (for review of growth patterns, see Anger 2001). As CHN and biochemical data have consistently shown, the steep initial growth phase is typically associated with a particularly fast accumulation of lipids (reflected by increasing C:N values and fat droplets in the hepatopancreas; cf. Figs. $3 \& 5$, Tables 3 \& 7), which can later be utilised as an endogenous energy source during periods of food limitation.

Hence, the rapid initial accumulation of biomass and energy allows for subsequent food-independent development in complete absence of food after the PRS, so that larvae may successfully moult to zoeae II, although they have 40 to $45 \%$ less biomass and significantly lower $\mathrm{C}: \mathrm{N}$ values than continuously fed control larvae. As a consequence, the biomass of newly moulted Zoeae II of Maja brachydactyla in our study was linearly correlated with the duration of initial feeding periods in the preceding Zoea I stage. This range of biomass at ecdysis is similar to values observed in preliminary experiments with the same species using mass-rearing techniques (Rotllant et al. 2010). Very similar relative figures were also obtained in experiments with another spider crab, Hyas araneus (Anger \& Dawirs 1982, Anger \& Spindler 1987), and in the portunid crab Carcinus maenas (Dawirs 1986). Interestingly, a newly moulted Zoea II originating from a PRS experiment may contain less 
biomass than a newly hatched Zoea I, still remaining viable and partially compensating the previous losses through a lengthening of the Zoea II moulting cycle (Anger \& Spindler 1987).

In conclusion, the present study corroborates previously proposed hypotheses on critical points and mechanisms of starvation effects within individual larval moulting cycles in majid crabs and other decapod crustaceans. For comparisons among different species or larval stages, however, $\mathrm{PNR}_{50}$ or $\mathrm{PRS}_{50}$ must be considered in relation to the moult-cycle duration of fed larvae reared under otherwise similar conditions, as environmental factors such as temperature and salinity may influence larval condition and development time. As another comparative index, Gebauer et al. (2010) recently proposed the NVI, defined as the quotient of $\mathrm{PRS}_{50}: \mathrm{PNR}_{50}$, which increases with increasing nutritional vulnerability and decreases with decreasing larval dependence on food availability. In majid spider crabs including Maja brachydactyla (present study) and Hyas araneus (Anger \& Dawirs 1981), low PRS and high PNR values, and consequently, NVI indices well below 1, indicated a relatively high level of early larval independence from food (for comparison of literature data, see Gebauer et al. 2010).

The activities of digestive enzymes (protease, amylase) that have been measured in larvae of Maja brachydactyla (Rotllant et al. 2008, 2012, Andrés et al. 2010b) reflect a strong capacity to digest food immediately from hatching. Under ad libitum conditions of feeding, the enzyme activities increased throughout the moulting cycle of Zoeae I, while continuously starved sibling larvae showed decreasing values. Also in successive larval stages of Hyas araneus, Hirche \& Anger (1987) and Harms et al. (1991) showed that trypsin and amylase activities increased during development, similar to the present study. The early appearance and developmental increase in protease activity of fed larvae indicates an immediate and continuously increasing need for protein degradation, which yields amino acids required for growth, morphogenesis and, probably to a lesser extent, as a metabolic energy source (Rotllant et al. 2010). However, a high level of variability among measurements of protease and amylase activities in otherwise similar larvae suggests that enzyme activities may be less suitable indicators of the nutritional condition of spider crab larvae. In conclusion, this study of the nutritional vulnerability of first-stage larval $M$. brachydactyla has shown that data on survival and development as well as those from determinations of $\mathrm{DM}, \mathrm{CHN}$, histological observations in the digestive gland and, to a lesser degree, those on digestive enzyme activities can be used as indicators of larval dependence on food and of physiological responses to transitory or extended period of food limitation. Although these individual variables differ in their respective explanatory power, a combined study of various criteria, in particular when these are considered in relation to the moulting cycle (Guerao et al. 2010), should allow for reliable assessments of the nutritional condition of early decapod larvae.

Acknowledgements. Bench fees were funded by INIA (RTA2008-00003-00-00 project) to G.R. Financial support was provided by the Ministry of Science and Research to G.G. (post-doctoral fellowship; INIA). We thank Glòria Macià for support as the hatchery and laboratory technician at IRTA, Sant Carles de la Ràpita.

\section{LITERATURE CITED}

Andrés M, Estévez A, Rotllant G (2007) Growth, survival and biochemical composition of spider crab Maja brachydactyla (Balss, 1922) (Decapoda: Majidae) larvae reared under different stocking densities, prey:larva ratios and diets. Aquaculture 273:494-502

Andrés M, Estévez A, Anger K, Rotllant G (2008) Developmental patterns of larval growth in the edible spider crab, Maja brachydactyla (Decapoda: Majidae). J Exp Mar Biol Ecol 357:35-40

Andrés M, Estévez A, Simeó CG, Rotllant G (2010a) Annual variation in the biochemical composition of newly hatched larvae of Maja brachydactyla in captivity. Aquaculture 310:99-105

Andrés M, Gisbert E, Díaz M, Moyano FJ, Estévez A, Rotllant G (2010b) Ontogenetic changes in digestive enzymatic capacities of the spider crab, Maja brachydactyla (Decapoda: Majidae). J Exp Mar Biol Ecol 389:75-84

Anger K (1987) The $\mathrm{D}_{0}$ threshold: a critical point in the larval development of decapod crustaceans. J Exp Mar Biol Ecol 108:15-30

Anger K (1995) The conquest of freshwater and land by marine crabs: adaptations in life-history patterns and larval bioenergetics. J Exp Mar Biol Ecol 193:119-145

Anger K (2001) The biology of decapod crustacean larvae. A.A. Balkema, Lisse

Anger K, Dawirs RR (1981) Influence of starvation on the larval development of Hyas araneus. Helgol Meersunters 34:287-311

Anger K, Dawirs RR (1982) Elemental composition (C,H,N) and energy in growing and starving larvae of Hyas araneus (Decapoda, Majidae). Fish Bull 80:419-433

Anger K, Harms J (1990) Elemental (CHN) and proximate biochemical composition of decapod crustacean larvae. Comp Biochem Physiol B Comp Biochem 97:69-80

Anger K, Spindler KD (1987) Energetics, moult cycle and ecdysteroid titers in spider crab (Hyas araneus) larvae starved after the $\mathrm{D}_{0}$ threshold. Mar Biol 94:367-375

Anger K, Storch V, Anger V, Capuzzo JM (1985) Effects of starvation on moult cycle and hepatopancreas of stage I lobster (Homarus americanus) larvae. Helgol Meeresunters 39:107-116 
Anger K, Harms J, Püschel B, Seeger C (1989) Physiological and biochemical changes during the larval development of a brachyuran crab reared under constant conditions in the laboratory. Helgol Meersunters 43:225-244

- Dawirs RR (1984) Influence of starvation on larval development of Carcinus maenas L. (Decapoda: Portunidae). J Exp Mar Biol Ecol 80:47-66

Dawirs RR (1986) Influence of limited food supply on growth and elemental composition ( $\mathrm{C}, \mathrm{N}, \mathrm{H}$ ) of Carcinus maenas (Decapoda) larvae, reared in the laboratory. Mar Ecol Prog Ser 31:301-308

Gebauer P, Paschke K, Anger K (2010) Seasonal variation in the nutritional vulnerability of first-stage larval porcelain crab, Petrolisthes laevigatus (Anomura: Porcellanidae) in southern Chile. J Exp Mar Biol Ecol 386:103-112

Giménez L, Anger K (2005) Effects of temporary food limitation on survival and development of brachyuran crab larvae. J Plankton Res 27:485-494

Giménez L, Anger K, Torres G (2004) Linking life history traits in successive phases of a complex life cycle: effects of larval biomass on early juvenile development in an estuarine crab, Chasmagnathus granulata. Oikos 104: 570-580

Guerao G, Pastor E, Martin J, Andrés M and others (2008) The larval development of Maja squinado and $M$. brachydactyla (Decapoda, Brachyura, Majidae) described from plankton collected and laboratory reared material. J Nat Hist 42:2257-2276

Guerao G, Rotllant G, Anger K (2010) Characterization of larval moulting cycles in Maja brachydactyla (Brachyura, Majidae) reared in the laboratory. Aquaculture 302: 106-111

- Harms J, Anger K, Klaus S, Seeger B (1991) Nutritional effects on ingestion rate, digestive enzyme activity, growth, and biochemical composition of Hyas araneus L. (Decapoda, Majidae) larvae. J Exp Mar Biol Ecol 145: 233-265

Hirche HJ, Anger K (1987) Digestive enzyme activities during larval development of Hyas araneus (Decapoda, Majidae). Comp Biochem Physiol B Comp Biochem 87:297-302

Humason GL (1979) Animal tissue techniques. WH Freeman, San Francisco, CA

Morgan SG (1995) Life and death in the plankton: larval mortality and adaptation. In: McEdward LR (ed) Ecology

Editorial responsibility: Christine Paetzold, Oldendorf/Luhe, Germany of marine invertebrate larvae. CRC Press, Boca Raton, FL, p 279-321

Paschke KA, Gebauer P, Buchholz F, Anger K (2004) Seasonal variation in starvation resistance of early larval North Sea shrimp Crangon crangon (Decapoda: Crangonidae). Mar Ecol Prog Ser 279:183-191

Pechenik JA, Estrella MS, Hammer K (1996) Food limitation stimulates metamorphosis of competent larvae and alters postmetamorphic growth rate in the marine prosobranch gastropod Crepidula fornicata. Mar Biol 127:267-275

Rotllant G, Moyano FJ, Andrés M, Díaz M, Estévez A, Gisbert E (2008) Evaluation of fluorogenic substrates in the assessment of digestive enzymes in a decapod crustacean Maja brachydactyla larvae. Aquaculture 282: 90-96

Rotllant G, Moyano FJ, Andrés M, Estévez A, Díaz M, Gisbert $E$ (2010) Effect of delayed first feeding on the nutritional condition of the spider crab Maja brachydactyla larvae. Mar Biol 157:2215-2227

Rotllant G, Guerao G, Sastre M, Anger K (2012) Developmental and moult-cycle related biochemical changes in larval spider crab, Maja brachydactyla (Brachyura, Majidae). Sci Mar doi:10.3989/scimar.03284.20A

Sokal RR, Rohlf FJ (1995) Biometry: the principles and practice of statistics in biological research, 3rd edn. W.H. Freeman, New York, NY

Staton J, Sulkin S (1991) Nutritional requirements and starvation resistance in larvae of the brachyuran crabs Sesarma cinereum (Bosc) and S. reticulatum (Say). J Exp Mar Biol Ecol 152:271-284

Storch V, Anger K (1983) Influence of starvation and feeding on the hepatopancreas of larval Hyas araneus (Decapoda, Majidae). Helgol Meersunters 36:67-75

Thatje S, Lovrich GA, Torres G, Hagen W, Anger K (2004) Changes in biomass, lipid, fatty acid and elemental composition during the abbreviated larval development of the subantarctic shrimp Campylonotus vagans. J Exp Mars Biol 30:159-174

Vogt G, Storch V, Quinitio ET, Pascual FP (1985) Midgut gland as monitor organ for the nutritional value of diets in Penaeus monodon (Decapoda). Aquaculture 48:1-12

> Yin M, Blaxter J (1987) Feeding ability and survival during starvation of marine fish larvae reared in the laboratory. J Exp Mar Biol Ecol 105:73-83

Submitted: April 11, 2012; Accepted: June 26, 2012

Proofs received from author(s): August 17, 2012 